\title{
Libri Principis e as llustrações de Flora e de Fauna do Brasil Holandês
}

\section{Libri Principis and Illustrations of Fauna and Flora of Dutch Brazil}

\author{
Dra. Cláudia Philippi Scharf
}

Como citar:

SCHARF, C.P. Libri Principis e as llustrações de Flora e de Fauna do Brasil Holandês. MODOS. Revista de História da Arte. Campinas, v. 4, n.2, p.123-142, mai. 2020. Disponivel em: <https://www.publionline.iar.unicamp.br/index.php/mod/article/view/4 554>. DOI: https://doi.org/10.24978/mod.v4i2.4554.

Imagem: Detalhe de "Paca", Libri Principis, A36, p. 226. Fonte: imagem digitalizada, disponível no site da Biblioteca Jaguelônica. 


\title{
Libri Principis e as llustrações de Flora e de Fauna do Brasil Holandês
}

\author{
Libri Principis and Illustrations of Fauna and Flora of Dutch Brazil
}

\author{
Dra. Cláudia Philippi Scharf*
}

\begin{abstract}
Resumo
Este artigo aborda um conjunto de ilustrações de flora e de fauna realizadas durante o governo de Maurício de Nassau no Brasil Holandês, no século 17, conhecido como Libri Principis: dois volumes encadernados com desenhos e pinturas realizadas entre os anos de 1637 e 1644 no Brasil, por artistas e cientistas de sua comitiva. Apesar de existirem por quase quatro séculos, os Libri Principis têm recebido pouca atenção, sobretudo de historiadores da arte, tendo sido considerados desaparecidos desde a Segunda Guerra Mundial até 1977, quando foram encontrados na Biblioteca Jaguelônica da Universidade de Cracóvia, na Polônia. $\mathrm{O}$ objetivo principal de minha pesquisa foi o de estudar esse material buscando conhecer sua trajetória histórica e investigar como, por que e por quem foi produzido. Para isso foi realizada uma revisão bibliográfica extensa e pesquisa sobre as técnicas pictóricas utilizadas pelos artistas viajantes da época. Entre as conclusões, destacamos 0 interesse e a estreita relação de Maurício de Nassau com 0 desenvolvimento da História Natural europeia e a inserção dos Libri Principis no amplo contexto do desenvolvimento artístico, científico e tecnológico do século 17.
\end{abstract}

\section{Palavras-chave}

Brasil Holandês. Libri Principis. llustração. História da arte. História natural.

\begin{abstract}
This paper deals with a set of illustrations of flora and fauna known as Libri Principis, carried out between the years of 1637 and 1644 in the 17th century in Dutch Brazil, during the government of Maurice of Nassau, by artists and scientists of his entourage. Although Libri Principis, with its two volumes bound with drawings and paintings, has existed for nearly four centuries, it has received little attention, especially from art historians, as it went missing during World War II and was only rediscovered in 1977 in the Jagiellonian Library of the University of Cracow, in Poland. The main aim of my research was to study this material in order to identify its historical trajectory and to investigate how, why and by whom it was produced. Accordingly, it was carried out a bibliographical review and a research on the pictorial techniques used by the traveling artists of the time. As conclusion, I highlight the interest and close relationship of Maurice of Nassau with the development of European Natural History and the insertion of Libri Principis in the broad context of artistic, scientific and technological development of the 17th century.
\end{abstract}

\section{Keywords}

Dutch Brazil. Libri Principis. Illustration. Art History. Natural History. 
Este artigo trata de um conjunto de ilustrações de flora e de fauna realizadas durante o governo de Maurício de Nassau no Brasil Holandês, no século 17, conhecido como Libri Principis ${ }^{1}$ (livros do príncipe): dois volumes encadernados com desenhos e pinturas realizadas entre os anos de $1637 \mathrm{e}$ 1644 no nordeste brasileiro, por artistas e cientistas de sua comitiva, produzidos de modo a construir uma iconografia dos animais e das plantas de seus domínios no Brasil. Apesar de existirem por quase quatro séculos, os Libri Principis (LP) têm recebido pouca atenção, considerados desaparecidos desde a Segunda Guerra Mundial até 1977, quando foram encontrados na Biblioteca Jaguelônica da Universidade de Cracóvia, na Polônia. Integram um conjunto maior chamado, atualmente, de Coleção Berlinka, composta de desenhos e pinturas sobre papel que incluem sete volumes: os Libri Principis (dois volumes), o Theatrum rerum naturalium Brasiliae (quatro volumes) e a Miscellanea Cleyeri (um volume $)^{2}$.

Trata-se de uma parcela da coleção de Nassau que foi cedida ao Eleitor de Brandemburgo, em 1652, em troca de dignidades nobiliárquicas e terras nos arredores de Cleves. Essa coleção contém 803 ilustrações sobre papel referentes ao Brasil Holandês, tendo sido utilizadas as técnicas de pintura a óleo, guache, aquarela, desenhos a lápis, carvão, pastel e nanquim. Dessas 803 ilustrações, apenas 13 possuem assinatura. Além da Coleção Berlinka, existem outros registros pictóricos da flora e da fauna nordestinas feitos no governo de Maurício de Nassau: desenhos e pinturas do artista Frans Post ${ }^{3}$ e do soldado Zacharias Wagener.

Com efeito, com a descoberta do Novo Mundo, se acentua o interesse pela história natural, a formação dos gabinetes de curiosidades por nobres e estudiosos, a necessidade de engajar artistas em expedições de exploração de novos territórios (e seus esforços na aplicação e desenvolvimento de técnicas para captação rápida e eficiente da realidade), e a estreita relação entre arte e ciência nesse período, que obedece a protocolos estabelecidos de produção visual científica. Nesta conjuntura, 0 projeto pessoal de Maurício de Nassau se insere no contexto colecionista europeu do século 17 (a partir do projeto colonialista iniciado no século 16) e, consequentemente, na conjuntura da ampliação e classificação de conhecimentos. Assim sendo, a coleção de Maurício de Nassau, sobretudo os Libri Principis, insere-se num contexto muito mais amplo que o da ocupação holandesa do nordeste brasileiro.

\section{História Natural e colecionismo}

A História Natural moderna foi assunto internacional no século 17: em diversos países, especificamente, em cidades como Praga, Bolonha, Nuremberg, Leiden, Paris e Londres, a prática da pesquisa era cultivada em cortes e universidades assim como em ambientes privados, em gabinetes, jardins e laboratórios. Remanescente da curiosidade renascentista, a ambição de conter uma infinita manifestação da natureza em um único espaço - chamado museu - se expande no século 16, quando a aventura ultramarina propicia os sonhos mais ousados.

No século 17 já era prática comum entre nobres e estudiosos a formação de um gabinete de curiosidades, como explica Françozo (2014: 54):

Foi no século 16, graças à expansão ultramarina dos europeus, que o interesse por objetos tomou as dimensões de uma efetiva prática colecionista, difundida entre nobres e burgueses em diversas cidades da Europa. Daquele momento em diante, estas coleções ficariam conhecidas como Kunstkammers ou Wunderkammers: coleções de arte, de maravilhas, de raridades ou curiosidades. 
Paralelamente, 0 interesse pela história natural se desenvolve sobremaneira na Europa com a ocupação sistemática do Novo Mundo. Novas espécies animais e vegetais, assim como o contato com grupos humanos antes desconhecidos instigam o interesse de estudiosos, de colecionadores e da população em geral. Os gabinetes de curiosidades são enriquecidos com espécimes de fauna, de flora e todo tipo de objeto curioso, diferente e/ou desconhecido.

Essa prática se consolida no Renascimento com o interesse por antiguidades greco-romanas e objetos exóticos vindos de terras pouco conhecidas, como o Oriente e o recém-descoberto Novo Mundo. 0 objetivo do gabinete era enquadrar e controlar 0 não-familiar: 0 objeto de prodígio ou de maravilhamento. Estes objetos eram classificados em mirabilia (objetos que surpreendem por sua raridade, evocando curiosidade e senso de admiração/respeito, dando prestígio ao colecionador), artificialia (combinação de trabalho da natureza com criação humana) e naturalia (fauna, flora e minerais, além de itens incrivelmente raros ou possuindo alguma afinidade com o mundo das fábulas seres deformados ou atípicos, como anões e gigantes, "chifre de unicórnio", fósseis e corais - que desafiavam a classificação convencional dos objetos naturais). Teriam como função representar o local onde foram encontrados e recolhidos (a parte pelo todo, segundo Mason, 1994: 2), possibilitando a reconstrução e entendimento do universo, divino e terrestre (Yaya, 2008: 174). Desta forma, o gabinete de curiosidades seria como um "microcosmo" do mundo conhecido, seu conteúdo formando um "teatro do mundo" (theatrum mundi).

Entre objetos de prodígio e objetos de investigação, as curiosidades serviam para retratar o universo e representar sua diversidade. Seja na intimidade do gabinete ou em atividades da corte, a história e a história natural se tornaram elementos inseparáveis, fundindo um passado antigo com o exotismo em voga, permitindo assim uma reconstituição do mundo conhecido (Yaya, 2008: 180). É importante ressaltar que no século 17 , sob a classificação de história natural estavam agrupadas disciplinas que hoje formam campos autônomos, tais como a astronomia, a meteorologia, a geografia, a botânica, e a zoologia (Gesteira, 2014: 18), assim como a filosofia da natureza englobava a física pura e a biologia geral.

O homem moderno precisava entender o mecanismo do universo e os motivos da sua diversidade, e para realizar tal tarefa, necessitava organizar e classificar o material que possuía. A popularidade ganha pelos os gabinetes de curiosidades refletia a necessidade de classificar e ordenar apropriadamente 0 conhecimento disponivel. Assim como outras ciências emergentes, a história natural surge, então, como uma estrutura de conhecimento que concebe o mundo como um caos a partir do qual o cientista produz uma ordem. Não se trata simplesmente de representar o mundo tal qual ele é, mas exige a intervenção humana (principalmente intelectual) para que se componha a ordem (Pratt, 1999: 65 e 78): "Cobrindo a superfície do globo, ela enquadrou plantas e animais em termos visuais, subsumindo-as e realocando-as numa ordem de feitura europeia, finita e totalizante". Dessa forma, os documentos dessa nova história são espaços claros onde as coisas se justapõem: herbários, coleções, jardins. Espaços intemporais onde, despojados de todo comentário, de toda linguagem circundante, os seres se apresentam uns ao lado dos outros, aproximados segundo seus traços comuns. 0 gabinete de história natural e 0 jardim expõem as coisas em quadro e 0 que se esgueirou entre esses teatros e esses catálogos não foi o desejo de saber, mas um novo modo de vincular as coisas ao mesmo tempo ao olhar e ao discurso: uma nova maneira de fazer história (Foucault, 2002 [1966]: 145).

Segundo Yaya (2008: 173), o fenômeno da coleção privada se desenvolveu dentro de um contexto intelectual que veio a ter uma imensa e unificante influência nos modos de coletar e classificar 0 conhecimento. Esse movimento intelectual envolvia não apenas 0 estudo das artes e técnicas 
desenvolvidas pelo gênio humano, mas também fenômenos extraordinários observados na natureza. $A$ compreensão do mecanismo que regula os fenômenos do engenho humano e da natureza forneceria a chave para o conhecimento do universo. Além da história e da história natural, a cosmografia estava preocupada com os padrões que estruturavam o universo, combinando o conhecimento astronômico com a geografia. Muitas cosmografias seguiram o conteúdo e os padrões das primeiras coleções.

O interesse por coleções de objetos exóticos é favorecido e incentivado pelo comércio ultramarino, fazendo com que viajantes lucrassem ao venderem seus objetos a príncipes e nobres detentores de um gabinete de curiosidades. A partir da segunda metade do século 16, certos indivíduos, aproveitando-se de posições estratégicas em postos de comércio, formaram seus próprios gabinetes de curiosidades, como Maurício de Nassau ao se tornar governador geral do Brasil Holandês.

Pensemos, então, na importância da Holanda no contexto do século 17, país europeu para onde convergiam mercadorias de todo o mundo conhecido, sobretudo pela atuação da Companhia das Índias Orientais e Ocidentais, favorecendo a formação de um ambiente cosmopolita e sofisticado, propício ao desenvolvimento das ciências e das artes, onde a existência dos gabinetes de curiosidades seria mais um fator favorável a esse desenvolvimento. Por exemplo, os territórios germânicos e neerlandeses abrigaram os mais importantes centros de publicação da Europa e foram os primeiros a fornecer crônicas ilustradas e relatos de viajantes, assim como numerosos poemas e sátiras políticas cujo tema era a América (Yaya, 2008: 178).

\section{llustração científica}

O estudo científico de plantas e animais, com avanços importantes da botânica e da entomologia, iniciase no século $16 \mathrm{e}$, como vimos, recebe um grande impulso com as viagens ultramarinas. A descoberta, coleta, transporte, cultivo e criação de plantas e animais exóticos em jardins e hortos europeus impulsionam o conhecimento científico e, com ele, a necessidade de estudo, classificação e registro das espécies. Desta forma, a ilustração científica surge como uma nova área - tanto no campo da arte como no da ciência - e os artistas, acompanhando os cientistas viajantes, são requisitados a suprirem essa demanda 4 .

É importante salientar a sincronicidade de vários eventos fundamentais no contexto europeu do século 17: a ruptura com a escolástica medieval; o desenvolvimento da História Natural com a ocupação do Novo Mundo; o crescimento do colecionismo (a partir do século 16), com a formação de gabinetes de curiosidades; a idade do ouro da arte holandesa, com sua ênfase na descrição; o desenvolvimento de tecnologias como o uso de lentes de aumento e o aperfeiçoamento do microscópio na Holanda (e sua utilização por artistas como recurso na reprodução de detalhes); o desenvolvimento científico do estudo de plantas e animais; o surgimento de pinturas de arranjos florais - florilégios ${ }^{5}$ - e o consequente desenvolvimento na técnica de representação de tal tema; o comércio e as viagens ultramarinas com comitivas de artistas e cientistas com o objetivo de produzirem um inventário textual e visual do Novo Mundo.

\section{0 desenvolvimento de métodos de registro visual}

Os naturalistas e artistas que integravam comitivas em viagens ultramarinas se valiam do uso de técnicas rápidas e eficazes para a captura de imagens, como o desenho a lápis ou carvão, a aquarela e/ou guache para colorir. Alpers (1999: 301) afirma que a técnica da aquarela foi favorecida pela técnica do desenho na Europa setentrional e que na Holanda do século 17, muitos dos desenhos de animais ou flores são executados nesta técnica, que é um meio que suprime a distinção entre desenho e pintura e foi originalmente empregada no interesse da instantaneidade da representação. Os esboços 
realizados in loco eram aprimorados posteriormente durante a viagem ou no retorno à Europa, onde seriam utilizados para a produção de gravuras para ilustração de livros ou pinturas a óleo.

A historiadora da arte Rebecca Parker Brienen (2006 e 2010) discorre sobre as técnicas utilizadas pelos pintores e naturalistas da comitiva de Maurício de Nassau, salientando que as imagens realizadas em solo brasileiro tinham um objetivo claramente científico e foram produzidas de acordo com os padrões vigentes à época. Estes padrões buscavam a fatura de imagens de flora e de fauna a partir do vivo, esmerando-se na representação o mais fiel possível da realidade, com a reprodução das cores e do habitat das espécies, além de textos explicativos acompanhando as imagens, buscando um rigor científico já em voga na época e tentando captar o máximo possível de informações sobre o espécime representado, incluindo detalhes anatômicos e dimensões.

Claudia Swan (2005: 9-10) ressalta que a história natural moderna assimilava espécimes desconhecidos do Novo Mundo através de uma densa descrição desses espécimes. Essas descrições dependiam largamente da evidência visual do espécime observado, que eram feitas através do domínio do registro de informações na forma de imagens. Assim, no decorrer do século 16, os avanços no conhecimento do mundo natural foram feitos pela via da produção de imagens, que ganhou urgência em função da recente tecnologia de impressão. Na virada do século 17 , a publicação de textos amplamente ilustrados - muitos na Holanda - descreviam, verbal e visualmente, o mundo das plantas e dos animais e os configurava de acordo com a prática classificatória da época. 0 imperativo do emprego da imagem para esse fim era que ela tinha o valor de verdadeira evidência visual.

Durante o século 16, um vocabulário específico surgiu e passou a ser largamente empregado para certificar a veracidade das imagens: em latim os termos contrafacta (literalmente "feito contra") e ad vivum ("ao vivo"), que em formas vernaculares transformaram-se em termos como naer het leven (holandês), nach dem Leben (alemão), al vivo (italiano), au vif (francês) e from life (inglês). Esses termos foram amplamente empregados em toda a Europa para descrever desenhos, pinturas e impressos, servindo para garantir a acurácia das imagens em relação ao que elas retratavam. No século 17, esses termos foram usados cientificamente ou no contexto da história natural para garantir a verificabilidade da descrição, designando uma mimesis particular e funcional (Swan, 2005: 10). Especificamente na Holanda, artistas que retratavam coisas "ao vivo", aderiam a um modo historicamente específico de representação. No caso das ilustrações produzidas no Brasil Holandês, Brienen (2010: 56) destaca:

Os desenhos e estudos a óleo brasileiros de Eckhout e Marcgraf foram concebidos numa época em que tanto os artistas quanto os cientistas tentavam descobrir a linguagem visual propícia à representação da natureza. (...) em um tempo marcado por uma fronteira imprecisa entre a arte e a ciência, convém dizer que ambas podiam ser consideradas modelos apropriados para projetos tão distintos entre si como a História Naturalis Brasiliae de Piso e Marcgraf (Fig. 1) e os cartões de tapeçaria executados para Gucht, em Delft, e para os Gobelins, em Paris.

Assim como os gabinetes de curiosidades continham objetos que representavam lugares longínquos e desconhecidos, a imagem de um espécime representava o próprio espécime, atestando a veracidade de sua existência, pois fora produzida a partir do espécime vivo e por alguém que esteve no seu habitat natural. Brienen (2006 e 2010) aproxima o conceito de contrafactum de Peter Parshall6 ao de ad vivum de Claudia Swan (2005). 


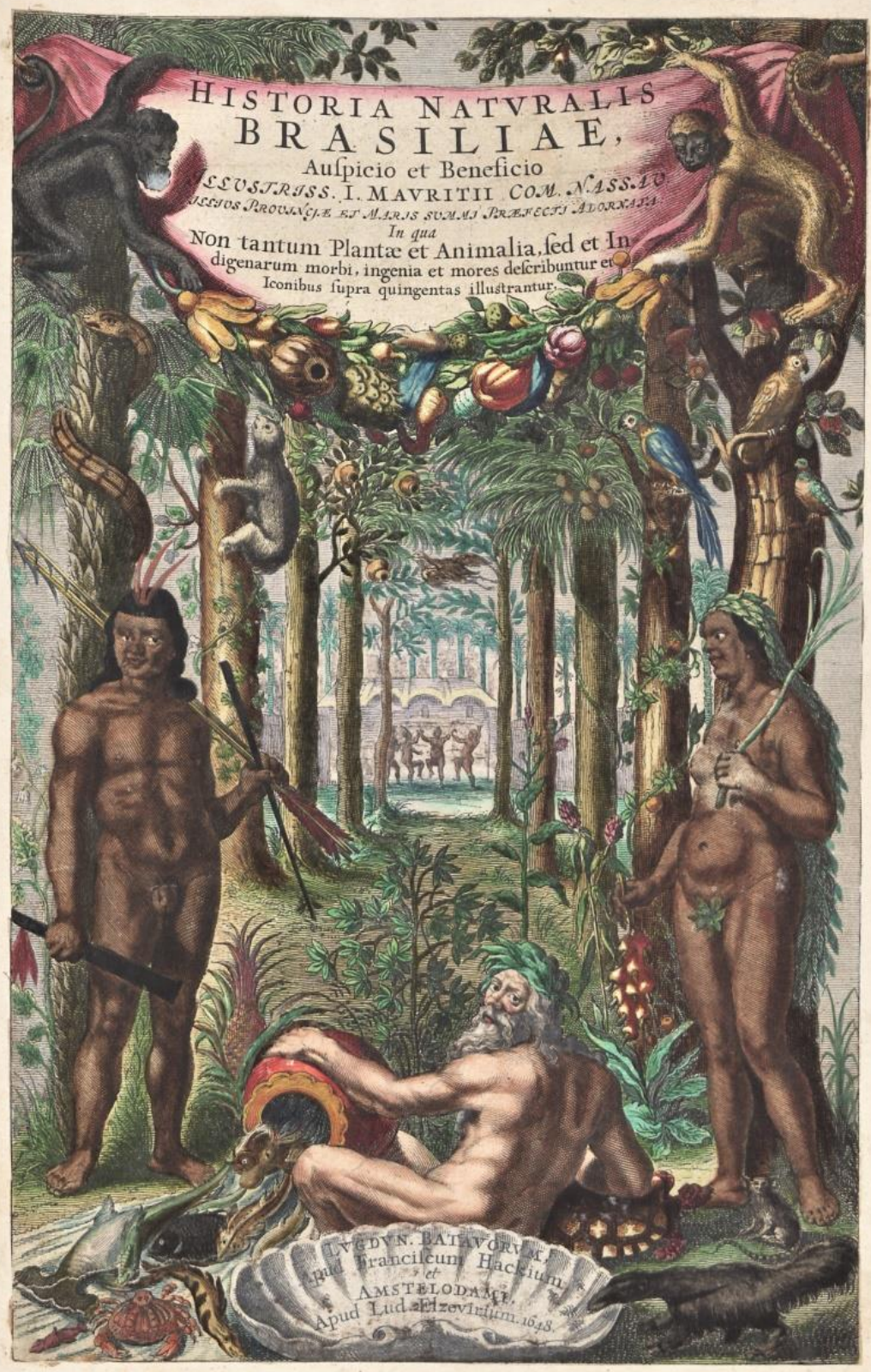

Fig. 1. Frontispício do livro Historia Naturalis Brasiliae, gravura em cobre, edição policromada de1648, em latim, p. 3. Fonte: imagem digitalizada do original, gentilmente cedida pelo Instituto Ricardo Brennand, Recife-PE.

O contrafactum atesta a correspondência da imagem ao original uma vez que este não está disponível para verificação. Da mesma forma, as imagens feitas ad vivum prometem conformidade com o tema retratado, uma correspondência icônica que lhes confere o status de documento. Muitas vezes, diversas ilustrações representam parte do habitat do espécime - o que era prática comum para as ilustrações de história natural, como demonstra Swan (2005) - e vêm acompanhadas de um texto de alguém que o viu com seus próprios olhos, a exemplo do material produzido pela equipe de Maurício de Nassau, com comentários manuscritos que acompanham parte das ilustrações. 
Entretanto, afirma Brienen (2006: 297), há poucas investigações sobre como combinações específicas de recursos visuais e características físicas (além da evidência linguística) podem ter feito um espectador acreditar que a imagem fosse um portador confiável de informações. Contradizendo esta afirmação, Alpers (1999: 233) argumenta que, para compreender a relação entre o artista holandês e a tradição técnica, é preciso considerar que, longe de repudiá-la, o artista do século 17 realizava sua obra declarando-se 0 melhor dos artesãos. A autora sustenta que as imagens, mais fortemente que os textos, são um meio de apreensão de novos conhecimentos sobre o mundo para os holandeses. Também escreve (Alpers, 1999: 37) que devemos olhar a arte holandesa circunstancialmente, buscando não somente vê-la como uma manifestação social, mas também acessar as imagens mediante a consideração de seu lugar, papel e presença na cultura mais ampla. A autora evoca Constantijn Huygens (secretário de Estado e figura cultural influente e compromissada com as artes na Holanda seiscentista), que liga as imagens à vista e à visão, especificamente ao novo conhecimento, tornado visível graças à recém-adquirida tecnologia das lentes.

Podemos supor então, no caso específico do Brasil Holandês, que o conhecimento de uma nova cultura ocorreu predominantemente pela captação de múltiplos aspectos através das imagens e que os holandeses as utilizaram como forma de catalogar e conhecer novos territórios e, ao contrário de outros relatos sobre o Novo Mundo e seus habitantes, as ilustrações em questão não corroboraram uma visão europeia fantasiosa de um Novo Mundo povoado por seres, animais e flora exóticos e fantásticos, que predominou nos séculos 16 e 17. Alpers (1999: 309 e 310) afirma ainda que:

A equipe sem precedentes de observadores ou descritores (se assim podemos chamálos) que o príncipe Maurício reuniu incluía homens peritos em história natural e em cartografia, e também em desenho e pintura. (...) Eles reuniram um registro pictórico único da terra brasileira, seus habitantes, sua flora e suas coisas exóticas. (...) Tal interesse na descrição deve ser colocado contra os relatos fabulosos do Novo Mundo, que ainda estavam na moda.

Conforme apresentado acima, podemos concluir, a partir da argumentação de Swan, Brienen e Alpers, que os cientistas e artistas da comitiva de Maurício de Nassau atuavam seguindo procedimentos padrão da história natural moderna, bem como do fazer artístico predominante na Holanda seiscentista. Maurício de Nassau, por sua vez, atuava, por um lado, como mecenas das ciências e das artes conduta condizente com os padrões vigentes para a nobreza - e, por outro lado, como fornecedor de informações importantes sobre os territórios sob domínio holandês para a Companhia das Índias Ocidentais e outras instituições holandesas, como a Universidade de Leiden.

Sendo assim, as ilustrações para história natural produzidas durante o período nassoviano no Brasil foram realizadas dentro de parâmetros de produção visual científica que estavam sendo definidos à época. Tiveram por objetivo descrever e reproduzir a natureza, buscando incluir a maior quantidade possível de informações para a criação de um inventário visual do novo território, produzindo, classificando e ordenando esse novo conhecimento, de forma a atender às demandas da história natural moderna, dos gabinetes de curiosidades, da grande quantidade de publicações na área e também dos interesses comerciais da Companhia das Índias Ocidentais.

\section{Artistas viajantes}

A preferência pela aquarela e pelo guache para produzir imagens da natureza tem sido bem documentada: personalidades tão diferentes quanto o naturalista alemão Conrad Gesner e 0 artista holandês Joris Hoefnagel utilizaram essas técnicas - 0 artista por sua precisão e delicadeza e o cientista por sua transportabilidade, facilidade de uso e secagem rápida (Brienen, 2006: 292). Vários artistas 
holandeses eram especialistas nesse gênero no século 17, incluindo Pieter Holsteyn II, que tem um amplo trabalho composto por desenhos aquarelados de animais da América do Sul (sendo várias dessas ilustrações muito similares às ilustrações da Coleção Berlinka, configurando mais um caso de apropriação e difusão dos registros visuais do Brasil Holandês).

Muitas vezes 0 artista ou cientista começava fazendo um simples desenho a lápis em papel, aplicando a seguir uma aguada, permitindo-lhe estabelecer formas e padrões para a subsequente aplicação de detalhes em aquarela ou guache. A figura 2 indica como teria sido a confecção das ilustrações dos Libri Principis: desenho do espécime sobre papel, seguido de superposições de camadas de aquarela para alcançar a volumetria e as tonalidades desejadas e finalização com o detalhamento de texturas, inacabadas nesse exemplo.

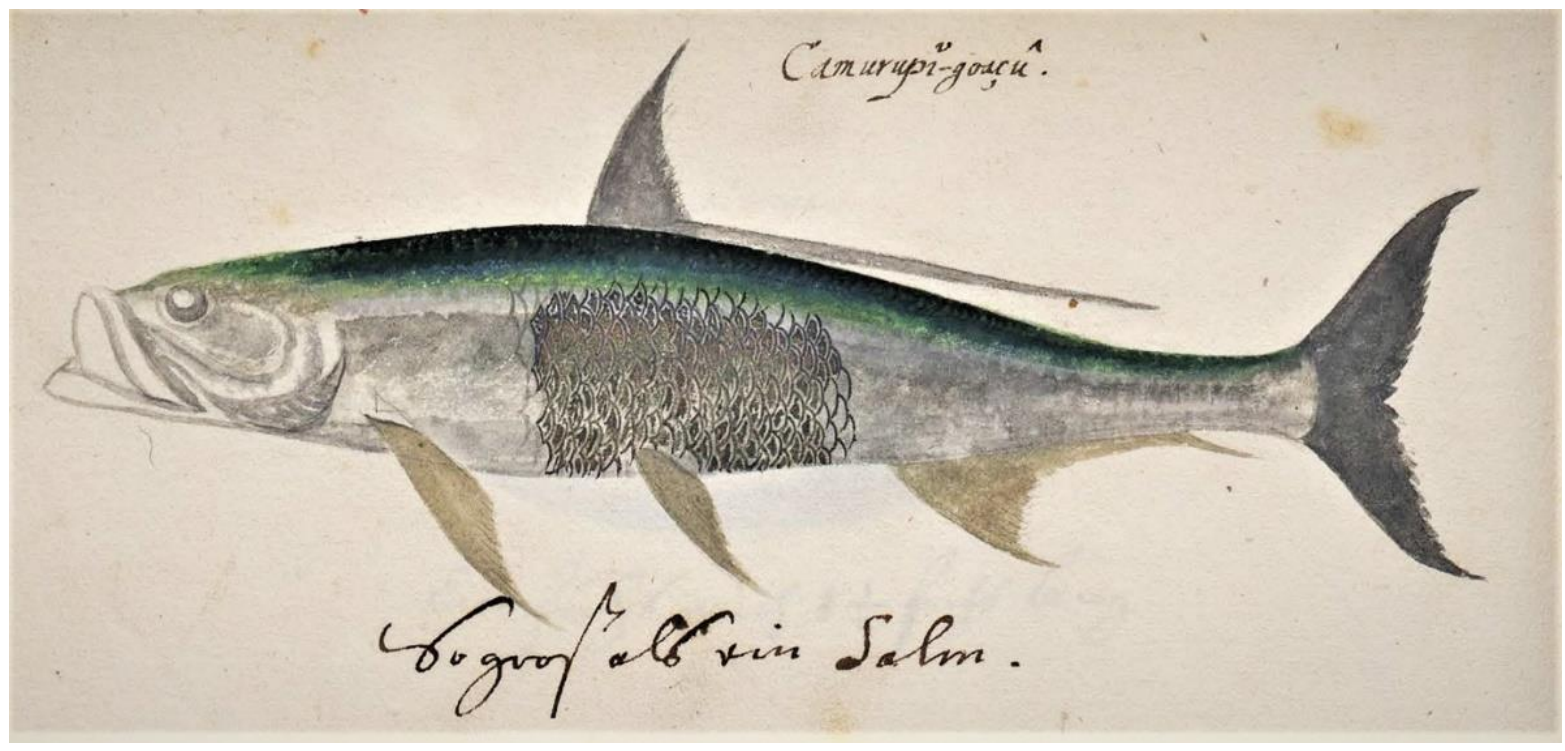

Fig. 2. "Camurupi-goaçû", LP A37, p. 305. Fonte: imagem digitalizada, disponível no site da Biblioteca Jaguelônica.

Este tipo de imagem transmite informações essenciais: permite reconhecer um animal e distingui-lo de espécies semelhantes, como a forma geral, a cor, o tipo de nadadeira ou pés, o número de nadadeiras ou de dedos dos pés, o comprimento da cauda etc. Na maioria das ilustrações, o espécime é representado de perfil, o que é característico dos estudos da natureza, bem como ilustrações de animais encontrados nos primeiros textos da história natural moderna. Imagens assim produzidas pretendem minimizar a presença do artista e seus poderes inventivos, demonstrando um relacionamento direto, individual, com a natureza: a principal preocupação dos ilustradores de história natural teria sido a transmissão de informações visuais precisas sobre os animais e as plantas. Por exemplo, Brienen (2006, p. 295) afirma que as ilustrações dos Libri Principis são contidas, relativamente bidimensionais e estáticas. $O$ artista teria rejeitado a sensualidade possível obtida com a tinta a óleo em favor da clareza da linha e da forma que caracterizam a aquarela e o guache.

No norte da Europa no século 16, as imagens passaram a ser produzidas e rotuladas mais comumente como fontes de informação visual precisa e não como exemplos de invenção artística. Swan (2005: 12) declara que, de acordo com a estruturação da prática artística no século 17, após 0 artista dominar todos os aspectos da representação de objetos reais, posturas ou características do mundo natural, ele progrediria para o reino da imaginação e da invenção. Segundo esse modelo estrutural, estudos 
preliminares feitos "ao vivo" seriam refinados através da esfera da imaginação. Ou seja, obras feitas "ao vivo" auxiliariam um esforço representacional mais complexo. Logo, podemos supor que artistas viajantes retratassem o novo universo que se descortinava diante de seus olhos não apenas com seu domínio técnico da representação, mas também com um esforço representacional mais complexo (esfera da criação). Os naturalistas ou os ilustradores para a história natural, por sua vez, deveriam abster-se de invenções criativas para retratar somente a "realidade", buscando uma representação o mais fiel possível do mundo natural, apenas utilizando o domínio técnico da representação, rechaçando qualquer possibilidade de uso da imaginação. Ou seja, as ilustrações de "naturalistas" pertenceriam à esfera científica e não à artística ${ }^{7}$, incluindo representações de história natural e ilustrações etnográficas em relatos de viagem.

A despeito de sua caracterização como artística ou científica, a ilustração de história natural tem ocupado um lugar marginal nos estudos da história da arte, que convencionalmente têm estipulado que obras de arte e imagens científicas diferem constitucionalmente e irreconciliavelmente: as primeiras são veículos de expressão estética, enquanto que as últimas transmitem informações quase anonimamente (Swan, 2005: 8). Esse tipo de pensamento, que prevaleceu no século 19, opunha arte e ciência: a subjetiva arte versus a objetiva ciência que emergia, da mesma forma que desenvolvia modelos disciplinares distintos para a arte e para a ciência (também para a história da arte e para a história da ciência), e tem ocultado significativas áreas sobrepostas (Swan, 2005: 9). Essa tradição parece elucidar o fato de ilustrações de história natural terem sido negligenciadas pela história da arte até recentemente, como declara Freedberg (1991: 411), Swan (2005: 8) e Alpers (1999: 310), tendo merecido atenção, sobretudo, de especialistas nas áreas das ciências naturais.

No caso específico dessa pesquisa, as ilustrações para a história natural, feitas pelos artistas e naturalistas de Maurício de Nassau, compreendem as técnicas do desenho a lápis, da aquarela e do guache sobre papel - George Marcgraf (Libri Principis), Zacharias Wagener (Thierbuch) e Frans Post (coleção do Arquivo de Haarlem, Holanda) - do desenho a lápis, carvão, nanquim, pastel e do óleo sobre papel - Albert Eckhout (Theatrum... e Myscellania Cleyeri).

\section{Técnicas de pintura}

Uma tinta é composta essencialmente de pigmento (partícula insolúvel finamente dividida) e aglutinante ou médium, que cumpre o papel de aglutinar as partículas de pigmento e, também, promover a adesão do conjunto ao suporte. $\mathrm{O}$ que diferencia as diferentes técnicas, portanto, é o aglutinante utilizado. Veremos, a seguir, algumas características da aquarela, do guache e do óleo, técnicas de pinturas utilizadas nas ilustrações estudadas nessa pesquisa.

A aquarela é composta essencialmente de pigmentos transparentes finamente moídos dispersos em solução aquosa de goma arábica (aglutinante e adesivo). O material aglutinante e o pigmento devem estar combinados na proporção correta para permitir que se realizem facilmente manipulações necessárias. Uma vez preparada, a aquarela pode ser diluída com água, pois continuará aderindo perfeitamente ao papel. A propriedade do papel de absorver e reter partículas de pigmentos em seus interstícios é tão importante quanto a adesividade da goma para fixar o pigmento ao suporte.

A técnica da pintura em aquarela se baseia num sistema de pigmentação por veladuras transparentes: na técnica tradicional se utiliza o branco brilhante do papel para todos os tons brancos e claros e, nas áreas coloridas, se aplicam pigmentos (que normalmente não são transparentes) muito diluídos, de modo que parecem tão brilhantes como os que são transparentes por natureza. Há também o método opaco de pigmentação, no qual se utiliza um pigmento branco para criar tons brancos. 0 uso de uma 
ou outra técnica (ou ainda a combinação das duas) depende do estilo do artista e dos efeitos que deseja obter. É possivel utilizar todos os pigmentos permanentes aceitos para pintar a óleo, exceto os que contêm chumbo. Os pigmentos que têm, por qualidade inerente, a transparência, como amarelo de cobalto, carmesim de alizarina e azul de magnésio, produzem efeitos muito brilhantes. Os pigmentos opacos, como os cádmios, também podem produzir efeitos transparentes se usados corretamente, aplicando-os em camadas muito finas e pouco pigmentadas. A aquarela se assemelha mais a uma tintura que a uma película contínua. No entanto, para pintar uma boa aquarela é necessário um grau considerável de habilidade e uma técnica artística bem desenvolvida. Como os materiais são portáteis, prestam-se muito bem para realização de estudos, portanto, há que se distinguir uma pintura em aquarela cuidadosamente realizada em estúdio ou ao ar livre de um estudo referência para uma obra posterior, que poderá ser realizada em aquarela ou em qualquer outra técnica. A pintura em aquarela só começou a ganhar reconhecimento artístico a partir do século 18, com a Escola Inglesa ${ }^{8}$.

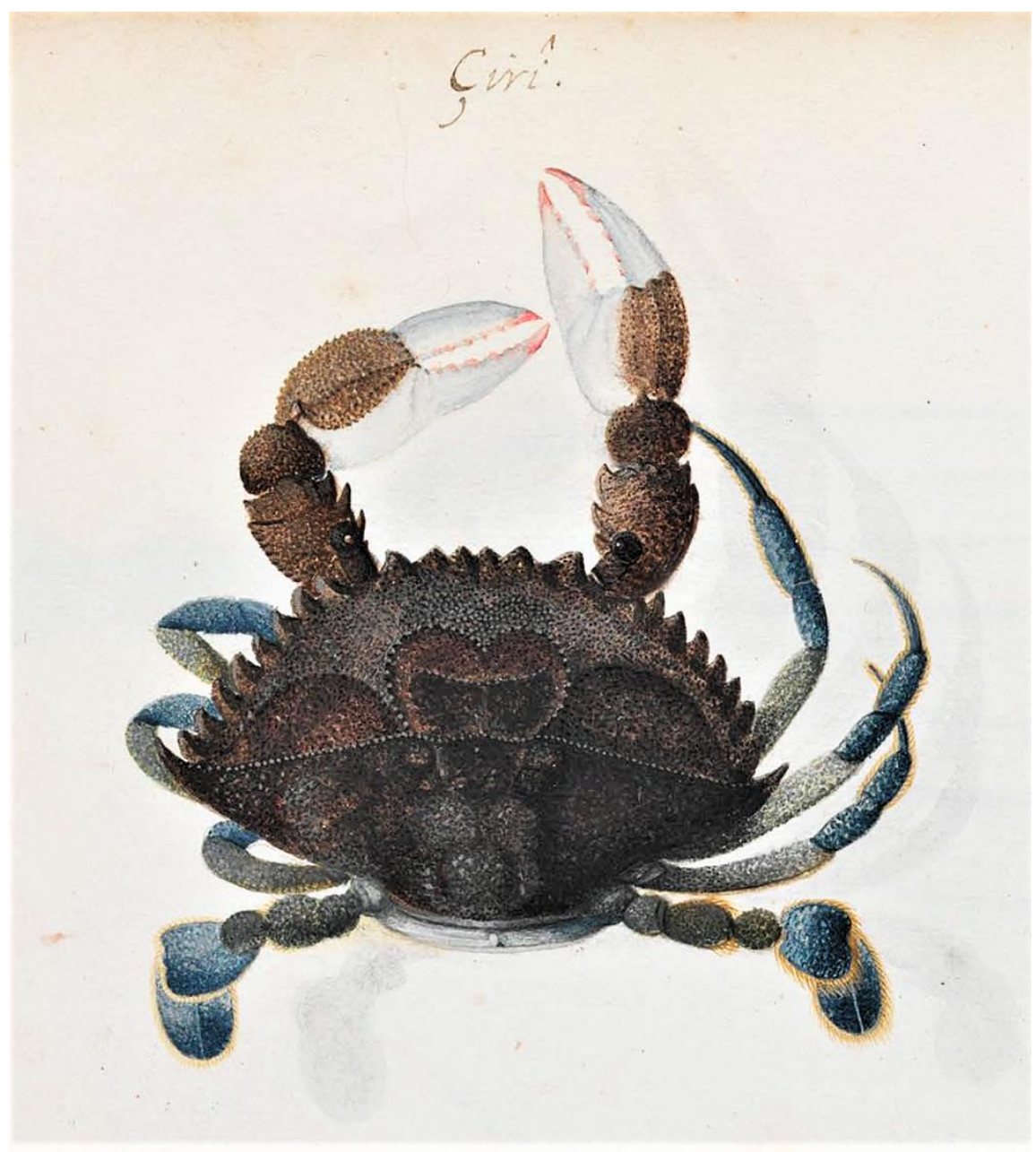

Fig.3. "Çiri", LP A36, p. 352.Fonte: imagem digitalizada, disponível no site da Biblioteca Jaguelônica.

Quando os materiais artísticos não eram industrializados, as aquarelas eram preparadas em pastilhas secas e comprimidas, posteriormente substituídas, em grande parte, por tubos de tinta úmida e semilíquida (que são mais utilizados por sua comodidade). As pastilhas secas são preparadas utilizando o pigmento seco misturado à goma arábica (ou do Senegal) concentrada, um pouco de fel de boi (umidificante, reduz a tensão superficial do líquido) e, ocasionalmente, açúcar, que atua como 
plastificador e facilita o manejo do pincel. A secagem da aquarela é uma simples questão de evaporação do diluente, a água, e não resulta em reações químicas que possam alterar sua natureza, como na pintura a óleo.

Existem muitos métodos, escolas e técnicas de pintura em aquarela. No método tradicional aplicam-se várias camadas de cor suave uma sobre a outra, obtendo-se um efeito aéreo luminoso. 0 brilho das aquarelas transparentes depende da base, que deve ser um papel branco puro, que reflita luminosidade.

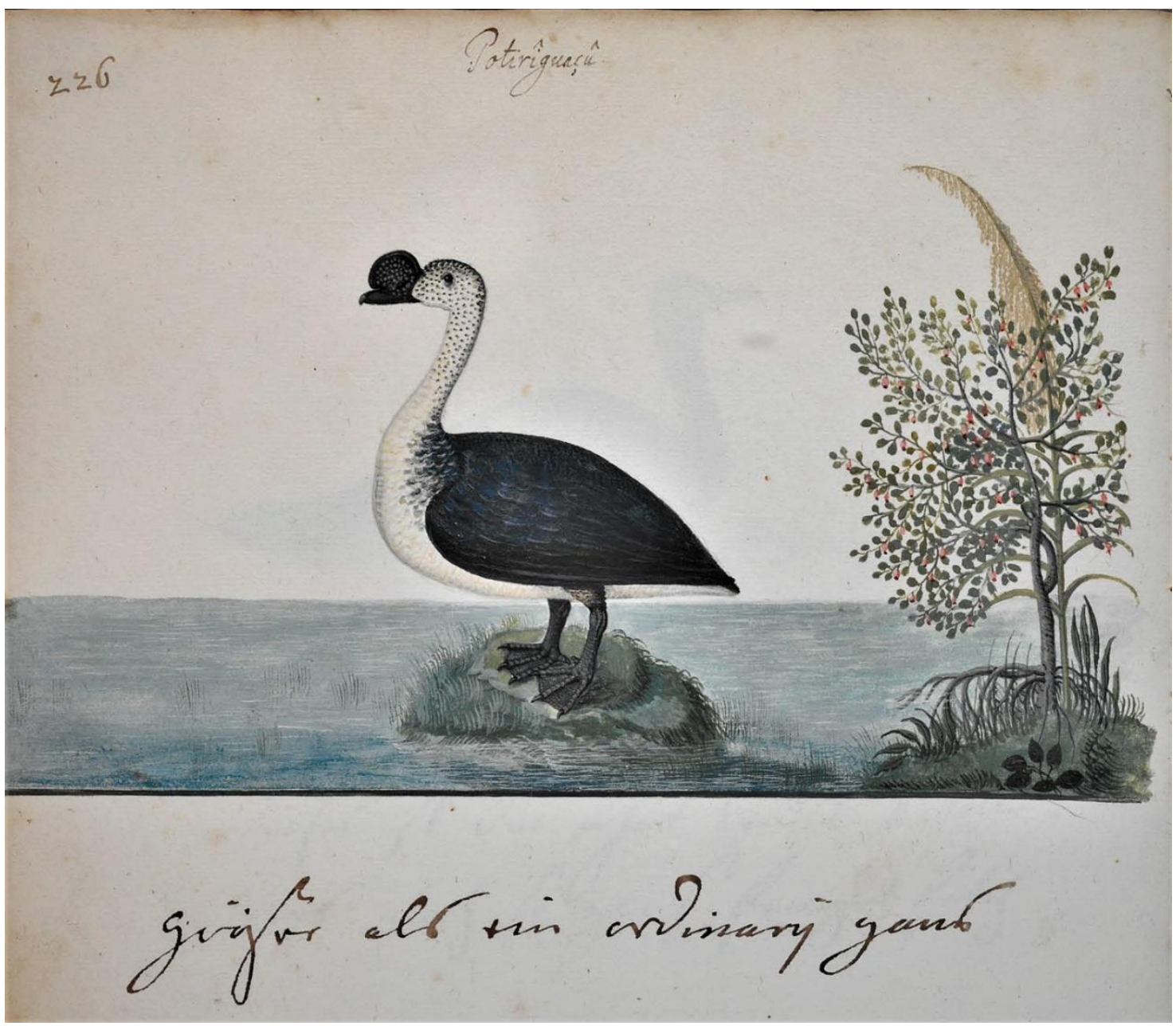

Fig.4. "Potirîguaçû", LP A36, p. 226. Fonte: imagem digitalizada, disponível no site da Biblioteca Jaguelônica.

O guache poderia ser considerado uma aquarela opaca, porém, é muito diferente da pintura transparente sobre papéis brilhantes que conhecemos como aquarela. A diferença entre aquarela e guache é que a primeira é pouco mais que uma mancha colorida no papel (não forma película de tinta) enquanto o guache forma uma verdadeira película com certa espessura. Um guache bem pintado não deve ter empastes nem camadas muito espessas de pintura que poderiam provocar craquelês, entretanto, o guache sempre produz o efeito de ser mais espesso ou rugoso do que realmente é. As pinturas em guache são opacas e têm ou deveriam ter poder de cobertura total. Têm uma qualidade brilhante, de sua própria natureza, que vem da superfície da pintura e seu brilho ou brancura se deve ao conteúdo de pigmentos brancos. 
Para se preparar tinta guache utilizam-se pigmentos finamente moídos, da mesma maneira que se usa para as aquarelas, porém com uma porcentagem muito maior de aglutinante e de pigmentos inertes, como preto ou branco para melhorar os efeitos de cor e textura, obtendo-se, dessa forma, um efeito opaco. Guaches de boa qualidade podem ser diluídos com água, funcionando como aquarelas, porém sem seu efeito brilhante. $O$ guache pode também ser usado como um tipo intermediário de pintura, a meio caminho entre seu efeito opaco e o brilho da aquarela, podendo-se também misturar esses dois tipos de pintura para obtenção de efeitos mais densos.

Procuro especificar as técnicas de pintura na análise das ilustrações dos LP no Capítulo IV de minha tese ${ }^{9}$. Aquelas cuja execução apresenta grande perícia e alto nível de precisão e fluidez parecem ter sido realizadas somente em aquarela [Fig.3]. Outras, de execução menos precisa e maior rigidez na pose, parecem ter sido realizadas com guache [Fig. 4]. Outras ainda, entre essas duas situações, parecerem ter sido realizadas com as duas técnicas, sobretudo com uso do guache na representação do ambiente/vegetação [Fig.5].

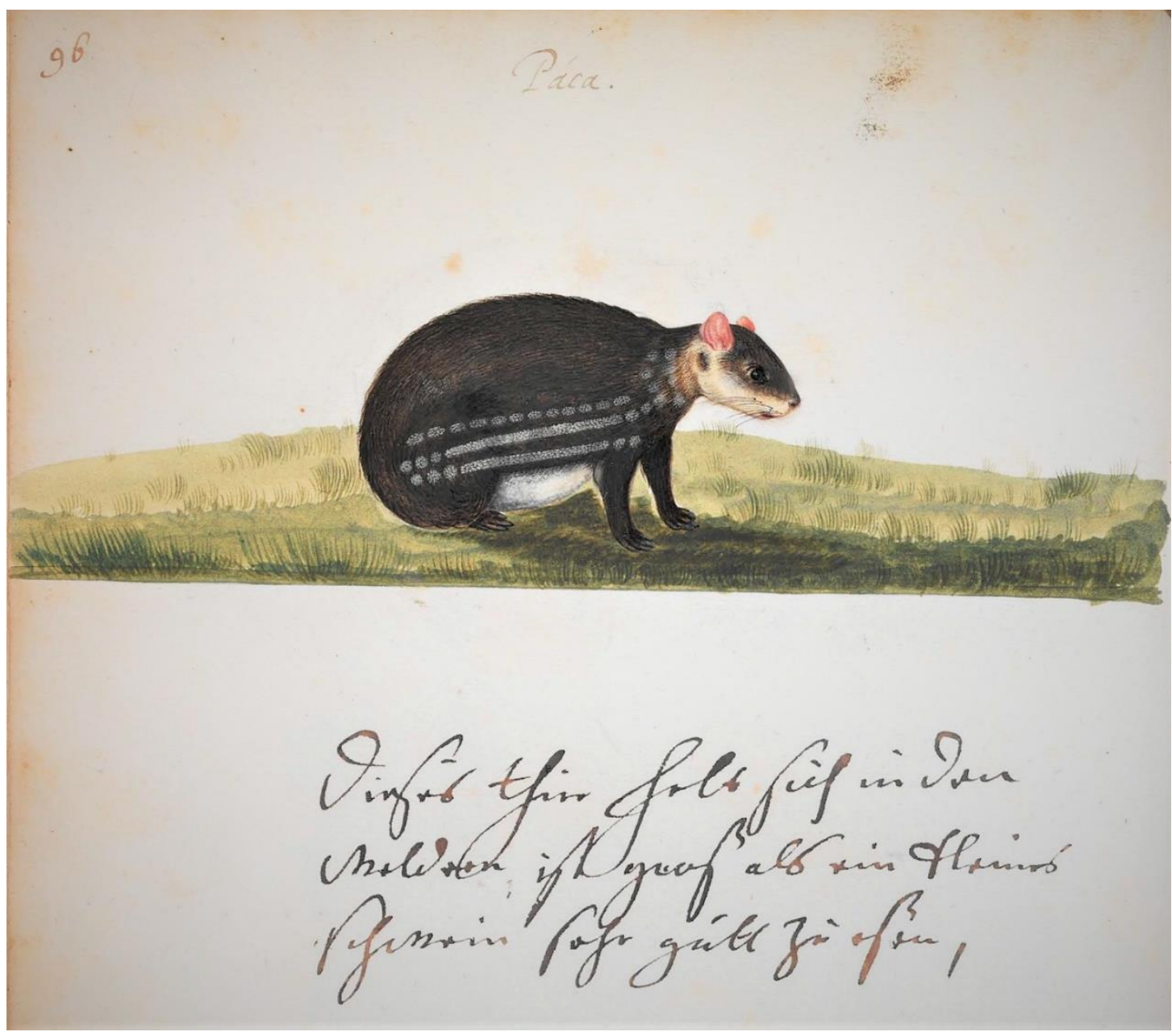

Fig. 5. "Paca”, LP A36, p. 226. Fonte: imagem digitalizada, disponível no site da Biblioteca Jaguelônica.

Uma terceira técnica de pintura foi utilizada nas ilustrações da Coleção Berlinka: tinta a óleo sobre papel. Essa técnica foi utilizada por Albert Eckhout na confecção de ilustrações do Theatrum... e da Miscellanea Cleyeri (MC), tratando-se de algo bastante incomum. Sendo exímios artesãos e confeccionando seu próprio material artístico, os pintores da época certamente possuíam conhecimento 
de que o aglutinante desse tipo de tinta, o óleo secativo (de linhaça, de nozes etc.), vai oxidando ao se combinar com o oxigênio do ar e, devido a várias reações químicas que ocorrem com o decorrer do tempo, vai endurecendo, perdendo flexibilidade e tornando-se mais transparente. 0 suporte tradicional adequado para a pintura a óleo é o painel de madeira ou o tecido esticado em bastidor. Em ambos os casos, o suporte deve receber uma camada de preparação que tem diferentes funções, entre elas, a de formar uma camada entre o suporte e a tinta a óleo a fim de impedir o contato com esta última, que iria oxidá-lo. No caso do suporte ser em papel, esse procedimento torna-se difícil, pois a aplicação de uma camada de preparação com espessura suficiente para isolá-lo do óleo incorporaria um peso indesejado, aumentando a espessura e causando perda de flexibilidade do papel; no entanto, não seria impossível aplicá-la. A inexistência de uma camada de preparação, ficando a tinta a óleo em contato direto com o papel, leva a uma degradação inevitável do papel, que não pode ser estancada, pois se trata de um fator de degradação inerente à técnica utilizada.

Brienen (2006: 298 e 299) afirma que pintar em óleo sobre papel era uma prática comum no sul (Países Baixos do Sul ou Flandres), mas bastante incomum entre os artistas holandeses no século $17 \mathrm{e}$ altamente incomum para produção de imagens da natureza. Ao contrário da aquarela, a pintura a óleo era empregada exclusivamente por artistas treinados e não por cientistas. A autora salienta que um exame cuidadoso dos originais revelou o método de trabalho de Eckout: o suporte (papel) foi preparado com uma camada de tinta que atualmente tem cor rosa amarronzada; a seguir, o artista fazia um esboço em giz e sobre este pintava em óleo, seguindo a técnica de pintura a óleo sobre tela (Brienen, 2010: $50)$.

Berlowicz (2002: 201) analisa pinturas de Eckhout, interpretando seu conteúdo e técnicas, e Christensen (2002: 211) faz uma investigação técnica sobre as pinturas de Eckhout, além de uma pintura de Post ${ }^{10}$, examinando os temas, a tela, o fundo, as camadas de pintura e assinaturas. Os pesquisadores concluem que, tanto no âmbito da técnica quanto dos materiais utilizados, nada foi encontrado de incompatível com o que é conhecido hoje sobre a pintura na Holanda seiscentista, comprovando que a produção desses pintores estava de acordo com os padrões artísticos da época, 0 que reforça a hipótese de que todos os materiais devem ter sido transportados ao Brasil.

Ao se observar as pinturas em óleo sobre papel de Eckhout, constata-se também que, em algum momento de sua existência, as pinturas receberam uma camada de proteção, ou seja, um verniz. Os vernizes de origem natural (não sintéticos) foram muito utilizados até meados do século 20 , com 0 objetivo de criar uma camada de proteção entre a camada pictórica (camada de tinta) e o ambiente, além de promover brilho e saturação das cores através da alteração do índice de refração da luz. É muito provável que nas imagens do Theatrum o verniz tenha sido aplicado com esses objetivos. No entanto, assim como a tinta a óleo, os componentes dos vernizes de origem natural, em contato com o oxigênio do ar, sofrem oxidação, amarelando e escurecendo com o passar do tempo. Essa característica era conhecida dos pintores e é notória entre os conservadores. Por essa razão, os vernizes eram removidos e substituídos, ou simplesmente reaplicados de tempos em tempos. No entanto, os vernizes de origem natural são de difícil remoção após oxidação e exigem solventes bastante tóxicos para sua solubilização e remoção, operação que nem sempre resulta em sucesso. Se o suporte é em papel, a remoção dessa camada é dificultada substancialmente devido à fragilidade do papel.

É possível que a técnica de pintura a óleo sobre papel tenha contribuído para a degradação física dos originais que estão na Polônia. Brienen (2006: 276, nota 9) ressalta que esses originais (que compreendem os Libri Principis, o Theatrum e a Myscellania Cleyeri) necessitam desesperadamente 
de conservação. Além disso, certamente o transcorrer do tempo, combinado com condições ambientais adversas sofridas, sobretudo, durante seu desaparecimento na Segunda Guerra Mundial até seu reaparecimento na Polônia, tenham contribuído com as degradações. Há ainda o verniz que independentemente da data em que tenha sido aplicado - também contribuiu para a degradação estética dos originais, pois escurecido e com transparência alterada pela oxidação, impede a visualização das cores originais das pinturas e do papel.

As ilustrações dos LP, feitas com a técnica da aquarela e do guache, não receberam envernizamento, porém, pode-se perceber nas reproduções da publicação da Editora Index, de 1995, e nos originais escaneados acessíveis no site da Biblioteca Jaguelônica, algumas degradações presentes na camada pictórica e no papel.

Muitos artistas desenvolveram métodos próprios de captura de imagens, como demonstra o Traité des Couleurs servant à la Peinture à l'eau, 1692, de A. Boogert, livro de 800 páginas sobre pinturas e aquarelas escrito em holandês. Boogert discute 0 uso das cores na pintura e explica como obter as diversas tonalidades, adicionando 1, 2 ou 3 partes de água [Fig.6].

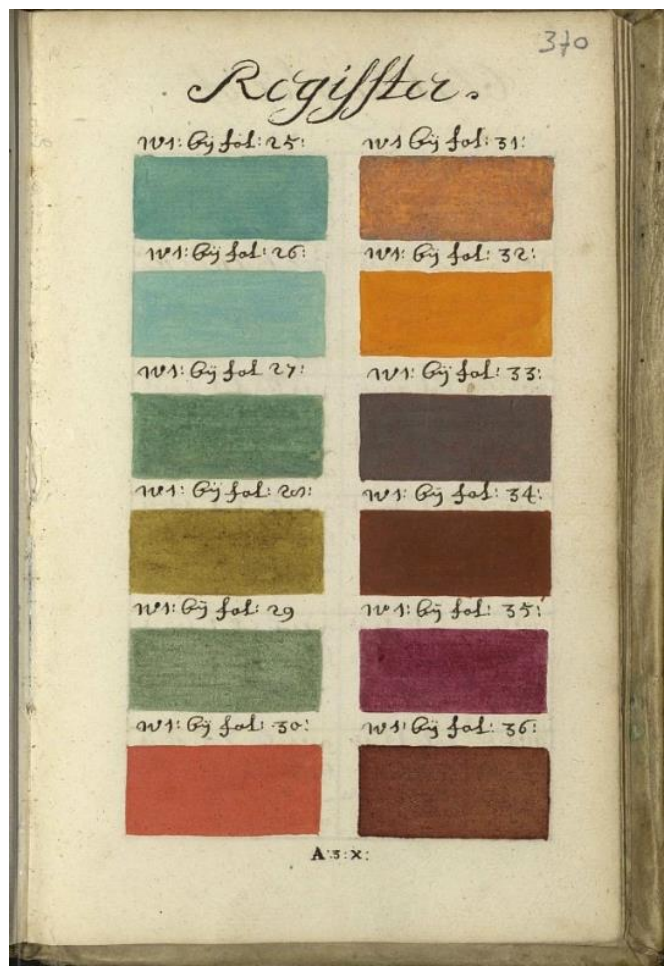

Fig. 6. Traité des Couleurs servant à la Peinture à l'eau, 1692, p. 826-827. Bibliothèque Méjanes, Aix-en-Provence, França. Fonte: $<$ https://bibliotheque-numerique.citedulivre-ix.com/records/item/35315-traite-des-couleurs-servant-a-la-peinture-a-leau>. Acesso em: 13 mai. 2019.

Outros artistas viajantes como Ferdinand Lucas Bauer (1760-1826), ilustrador que viajou em expedição para a Austrália, criaram seus próprios métodos para retratar a natureza de forma 0 mais realista possível. Segundo Martyn (2014: 95):

O método de trabalho de Ferdinand Bauer no campo foi excepcional; ele desenhou os espécimes a lápis e anotou a cor de cada folha ou flor em referência a uma cartela de cores numerada que criou. Na volta à Inglaterra, ele usou essas anotações para concluir 
a pintura. Alguns dos seus desenhos a lápis, com referência às cores enumeradas, hoje estão em Viena. As primeiras cartelas de cores de Bauer, com 150 tonalidades, sobreviveram: porém, sua cartela de cores grega, com 250, e a australiana com 992 tons de cores parecem não ter sobrevivido; existiam 200 tons de verde e 100 de rosa, vermelho, roxo, etc., que mostram o cuidado que ele tomou para reproduzir as cores das plantas vivas com a maior perfeição possível.

A figura 7 mostra o complexo sistema de código de cores usado por Bauer, no qual cada tom de cor era designado por um código numérico de até quatro algarismos, capacitando-o a desenhar um espécime enquanto ele ainda estava fresco e antes que suas cores naturais se modificassem. Mais tarde, quando ele iniciava sua versão em aquarela, podia reproduzir os tons originais com grande precisão [Fig. 8 e 9].

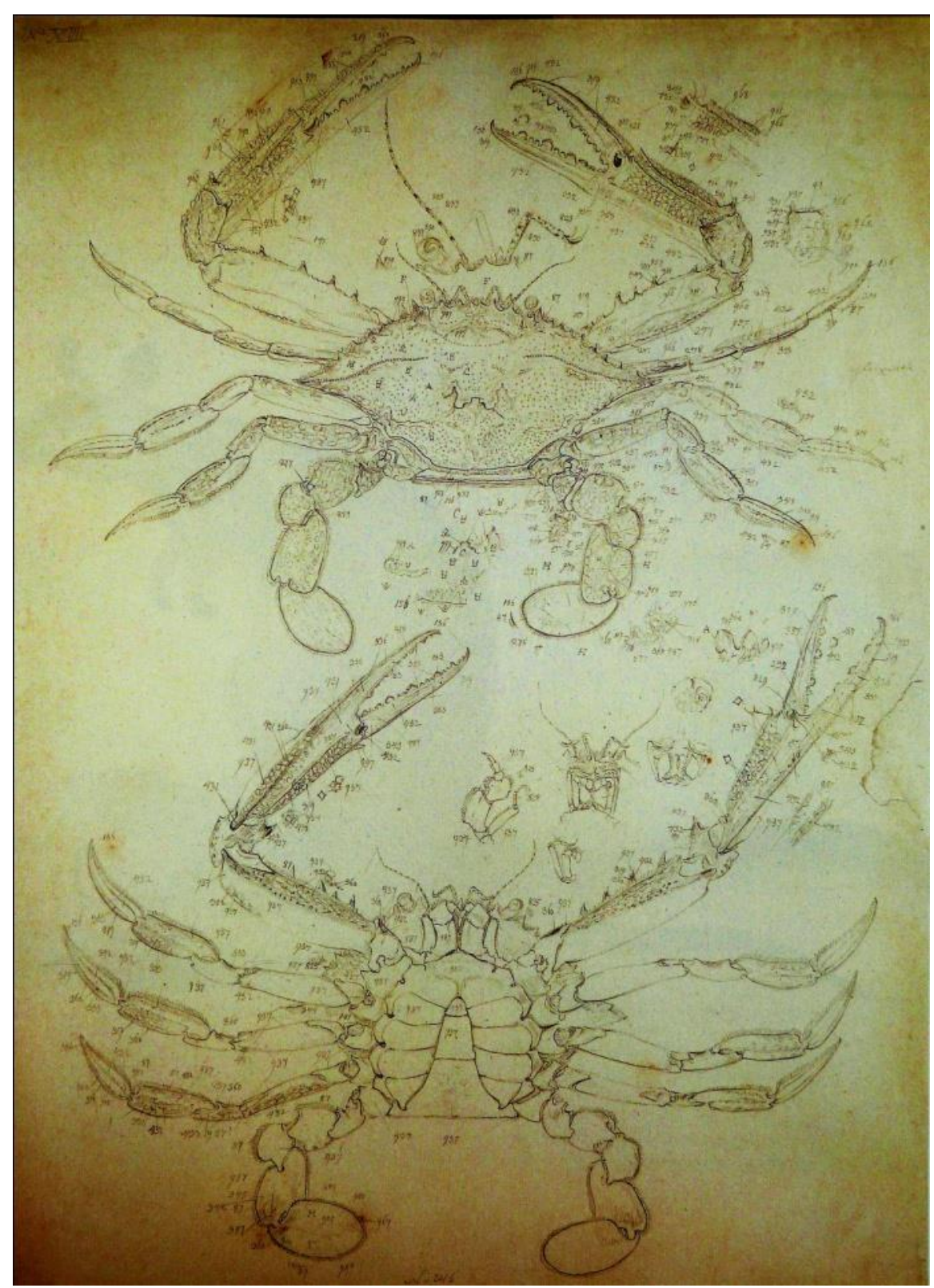

Fig. 7. O sistema de código de cores utilizado por Bauer. Fonte: RICE, 1999: 221. 


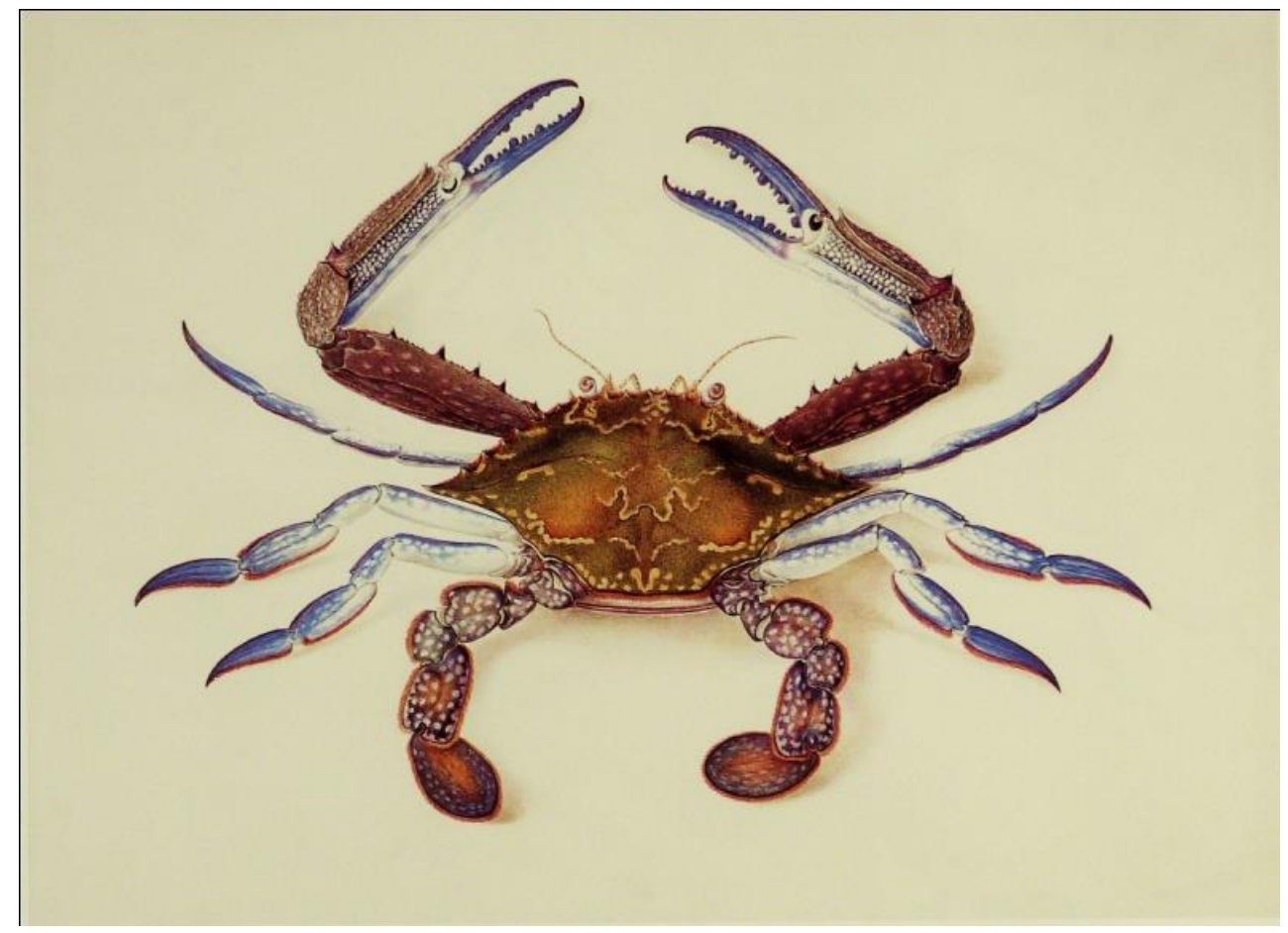

Fig. 8. O espécime com suas cores originais reproduzidas em aquarela. Fonte: RICE, 1999: 222.

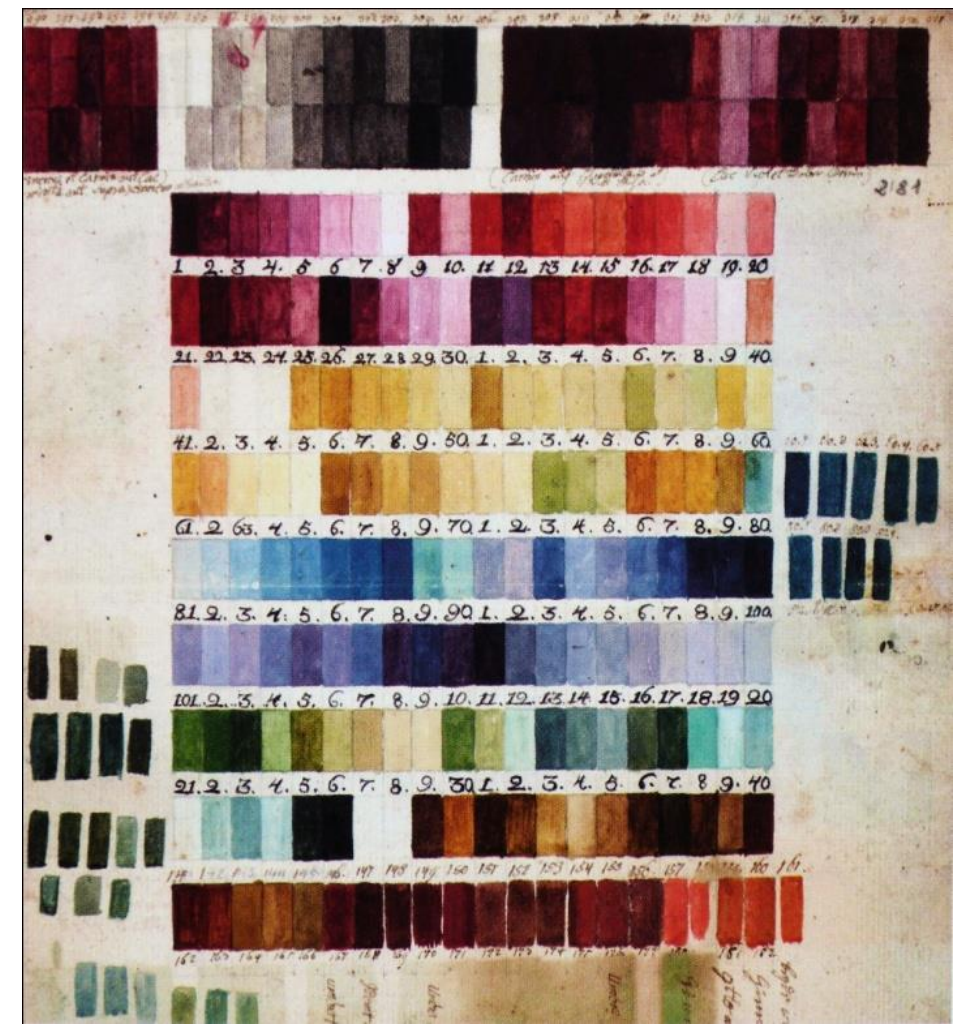

Fig. 9. Cartela de cores de Ferdinand Bauer mostrando as variações nas tonalidades e a numeração que ele usou para cada uma delas. Fonte: RICE, 1999: 222. 
Como argumentado anteriormente, não se pode esquecer que no século 17 os materiais artísticos não eram industrializados e que os artistas holandeses eram exímios artesãos e habitavam uma região onde era possível encontrar os mais variados artigos provenientes dos mais longínquos rincões do planeta. Entretanto, a preparação dos materiais artísticos exigia tempo, além de instrumentos e materiais específicos [Fig. 10], o que leva a indagar como se deu a produção de obras no Brasil Holandês. Podemos supor que os pintores da comitiva de Nassau, Frans Post e Albert Eckhout, produziram grande número de pinturas - com diversos temas - já levando em consideração os interesses científicos da comitiva. $O$ médico Willem Piso e o naturalista George Marcgraf pretenderam fazer um registro minucioso da fauna e da flora brasileiras, com objetivo claramente científico. Consideremos também a ênfase na descrição presente na formação artística e no imaginário dos pintores dos Países Baixos, a utilização de lentes de aumento (e, eventualmente, de microscópio) para observação e representação minuciosa de plantas e animais, e o conceito da representação ad vivum integrado à arte e ao fazer científico holandês. $O$ resultado é um impressionante inventário visual da fauna, flora, paisagens terrestres e marinhas, tipos humanos e arquitetura. $O$ registro da fauna e da flora - que não poderia ser considerado ilustração botânica e zoológica pelos padrões da ciência atual - esmerava-se, entretanto, na representação o mais verossímil possível da realidade, com a reprodução de cores e do habitat das espécies, além de textos explicativos acompanhando as imagens, buscando um rigor científico já em voga na época.

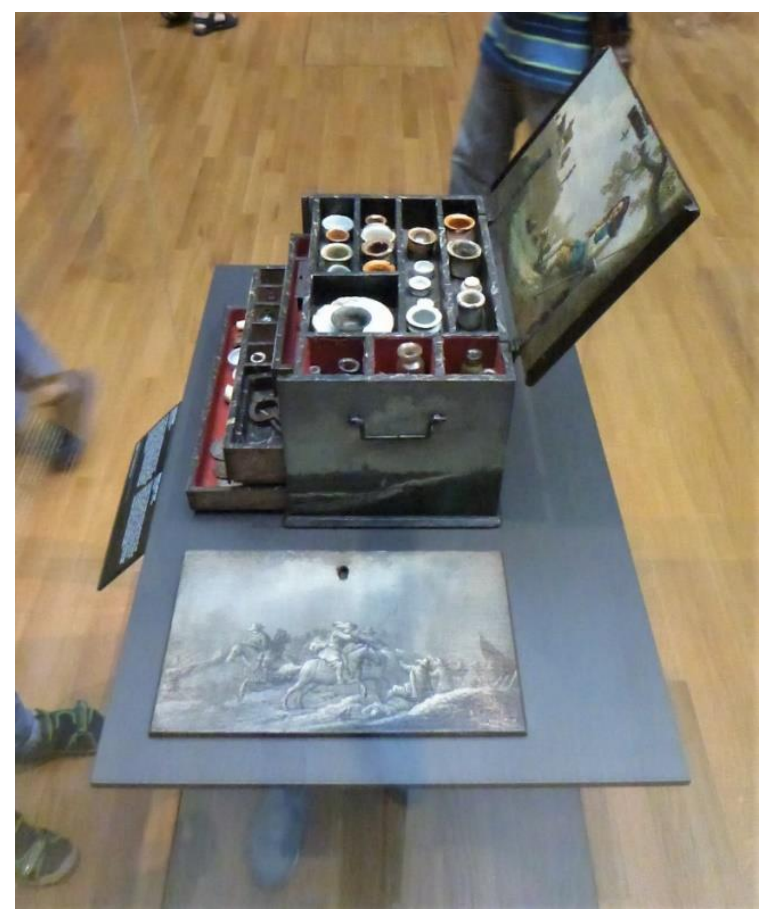

Fig.10. Caixa de pintura em carvalho, com potes de tintas a óleo, (c. 1640-1660), Rijksmuseum, Amsterdam. Fonte: acervo da autora, junho de 2017.

As imagens produzidas a lápis, nanquim, pastel, aquarela, guache e óleo pela comitiva de artistas e cientistas de Maurício de Nassau foram importantes protótipos para uso posterior: transformaram-se em gravuras, pinturas em óleo sobre tela, pinturas murais e tapeçarias, mesmo após a morte de seus autores. Foram copiadas e reproduzidas por seus contemporâneos e extemporâneos e, provavelmente, mais exemplares do que é conhecido hoje circularam por coleções privadas. No início do século 18 , 
segundo Joppien (1979: 298), a maioria das grandes cortes da Europa (Berlin, Copenhagen, Dresden, Paris, São Petersburgo) foram afetadas pelas repercussões da Coleção Brasiliana de Maurício de Nassau.

\section{Conclusão}

Várias questões foram apontadas acima quanto às implicações da produção de ilustrações científicas para a história e, especificamente, para a história da arte. A argumentação apresentada por historiadores da arte que apontam para a falta de estudos sobre a produção de imagens para a história natural no Brasil Holandês demonstra a necessidade de pesquisas mais profundas com esse propósito. Pesquisas não só no âmbito da história e da história da arte, mas também da história da arte técnica e da ciência da conservação. As ilustrações dos Libri Principis são fruto do desenvolvimento da configuração geopolítica europeia no século 17 e de parâmetros epistemológicos da história natural: foram produzidas e organizadas de acordo com protocolos estabelecidos para registro visual de novas espécies. Isto as coloca numa posição diferenciada em relação às demais ilustrações sobre papel da comitiva de Nassau (Theatrum... e MC), pois somente elas parecem ter sido produzidas com interesse exclusivo no registro de espécies, ou seja, para história natural.

Podemos, portanto, constatar o quanto ainda precisamos conhecer a respeito das técnicas, da fatura e dos métodos utilizados e, por que não, desenvolvidos pelos artistas viajantes na tentativa de reproduzir, da melhor maneira possível, novas espécies encontradas em suas jornadas. Contudo, as peculiaridades e individualidades inerentes a cada artista permanecem presentes em suas obras, apesar do rigor científico buscado, o que nos abre um importante caminho para pesquisas sobre a fronteira entre ciência e arte, constatando-se o quanto ela pode ser tênue e obscura e como os interesses da arte e da ciência convergem de forma espetacular na produção dessas ilustrações.

\section{Referências}

ALPERS, S. A arte de descrever: $A$ arte holandesa no Século XVII. São Paulo: EdUSP, 1999.

BAIER, R., BERLOWICZ, B. \& CHRISTENSEN, M. C. Albert Eckhout's Brazilian Paintings. In: Conservation of the Iberian and Latin American Heritage, ICC Madrid Congress, Madrid: 1992.

BRIENEN, R.P. Albert Eckhout: visões do paraíso selvagem (obra completa). Rio de Janeiro: Capivara, 2010.

From Brazil to Europe: The Zoological Drawings of Albert Eckhout and Georg Marcgraf. In: Intersections: Yearbook for Early Modern Studies, vol. 6, 2006.

FOUCAULT, M. As palavras e as coisas. São Paulo: Martins Fontes, 2002 [1966].

FRANÇOZO, M. De Olinda a Holanda: O gabinete de curiosidades de Nassau. Campinas: Ed. da Unicamp, 2014.
FREEDBERG, D.; VRIES, J. de. Art in history, History in art: Studies in seventeenth-century Dutch culture. Santa Monica: The Getty Center for the History of Art and the Humanities, 1991.

GESTEIRA, H. O Recife Holandês: História natural e colonização neerlandesa (1624-1654). Revista da SBHC 2 (I), 2004, p. 6-21.

JOPPIEN, R. The Dutch Vision of Brazil. Johan Maurits and his artists. In: Boogaart, E. (org.). Johan Maurits van Nassau-Siegen 1604-1679. Essays on the occasion of the tercentenary of his death. The Hague: The Johan Maurits van Nassau Stichting, pp. 297-376, 1979.

MARTINS, A. C. (org.). Flora brasileira: história, arte \& ciência. Rio de Janeiro: Casa da Palavra, 2009.

MARTYN, R. A era de ouro da arte botânica. São Paulo: Ed. Estampa, 2014.

MASON, P. From Presentation to Representation: Americana in Europe. In: 
Journal of the History of Collections, v. 6, n. 1, pp.1-20, 1994.

PRATT, M. L. Os Olhos do Império: relatos de viagem e transculturação. São Paulo: EDUSC, 1999.

RICE, T. Voyages of Discovery: Three Centuries of Natural History Exploration. New York: Clarkson Potter Publishers, 1999.

SCHARF, C. P. Libri Principis e as llustrações de Fauna do Brasil Holandês: fatura, técnicas, materiais e autores. Tese (Doutorado em Artes Visuais). Salvador: EBA/UFBA, 2019. llustração Científica no Brasil Holandês: a natureza retratada nos desenhos, pinturas e gravuras dos viajantes do séc. 17. In: Anais do XXXVII Colóquio do Comitê Brasileiro de História da Arte: História da Arte em Transe. p. 428-442. Salvador: CBHA, 2018 [2017].

SWAN, C. Art, Science, and Witchcraft in Early Modern Holland. Cambridge: Cambridge University Press, 2005.

YAYA, I. Wonders of America: The curiosity cabinet a site of representation and knowledge. Journal of the History of Collections, 20 (2): 173188, 2008.

\title{
Notas
}

\begin{abstract}
* Doutora em Artes Visuais (UFBA), Mestre em Artes (UQAM, Canadá), Especialista em Conservação-Restauração de Bens Culturais Móveis (CECOR/UFMG). Pesquisa financiada pela CAPES. E-mail: <claudiamemoria@hotmail.com>. ORCID: <https://orcid.org/00000002-5349-4599>
\end{abstract}

${ }^{1}$ Essa denominação se deve ao fato de cada imagem vir acompanhada de uma frase ou parágrafo escrito por Maurício de Nassau, cujo curto texto tece algum comentário a respeito da imagem (Figs. 2, 3, 4 e 5) ou, talvez, pelo fato de que Nassau tenha encomendado sua confecção.

2 Parte das imagens dos quatro volumes do Theatrum... é atribuída ao pintor Albert Eckhout, tendo sido analisadas por Brienen (2010), que também atribui a Eckhout a autoria de parte das imagens da MC.

${ }^{3}$ Em 2010 foi descoberto um conjunto de 34 estudos de Frans Post no Arquivo de Haarlem, na Holanda: desenhos coloridos (em guache e aquarela) de animais da fauna brasileira, que aparecem nas suas pinturas em óleo sobre tela.

${ }^{4}$ Martins (2009: 35) afirma que "muitos artistas ajudaram a dar visibilidade aos trabalhos botânicos. Os grandes livros ilustrados sobre flora e fauna, bem como os atlas pitorescos da época, além do valor científico estrito, eram muito procurados em função de sua beleza. Por ocasião da publicação dos resultados das viagens, não era raro que fossem arregimentados os melhores pintores de história natural da Europa".

5 Segundo Martyn (2014: 34): "Florilégios (do latim florilegium, "compilação de flores") impressos foram produzidos na Europa, particularmente na França, na Alemanha e nos Países baixos, durante o século 17, refletindo o aumento do interesse em ciências e filosofia que prevalecia na época. A primeira coleção de ilustrações realmente descrita sob o título de Florialegium foi provavelmente publicada pelo artista flamengo Aedriaen Collaert, na Antuérpia, em 1600".

${ }^{6}$ Peter Parshall (apud Brienen, 2006: 296), conceitua contrafactum: "o tipo ou a classe de representação designada por contrafactum veio a ser determinada principalmente pela intenção de transmitir alguma partícula de informação considerada transmissível através de uma imagem". Especialmente nos casos em que o original não está disponível para fins de verificação, tal designação foi considerada necessária para garantir ao público a precisão da representação.

${ }^{7}$ Swan (2005: 8) argumenta que qualquer análise desse tipo de ilustração confrontará a questão da relação recíproca entre arte e ciência na era moderna. A partir da Renascença o argumento convencional estabelece que a ciência serve à arte dando-lhe ferramentas técnicas tais como a perspectiva e a ótica, ou a arte serve a ciência pela nova capacidade de retratar o mundo e seus objetos naturalisticamente, ou ambos.

${ }^{8}$ Quando se começou a utilizar a aquarela para obras de arte definitivas, em princípios do século 18.0 método tradicional inglês consiste em superpor finas aguadas de cores delicadamente misturadas até que alcancem a profundidade e 0 efeito desejados. Geralmente a composição se baseava em um desenho a lápis cuidadosamente executado.

${ }^{9}$ Ver Referências Bibliográficas.

${ }^{10}$ Apesar da maioria das pinturas de Post terem sido executadas na técnica do óleo s/ tela, há duas pinturas desse artista no acervo do Instituto Ricardo Brennand, em Recife-PE, com a técnica do guache e tempera s/ papel, datadas de 1640 portanto, pintadas no Brasil.

Artigo recebido em fevereiro de 2020. Aprovado em abril de 2020. 